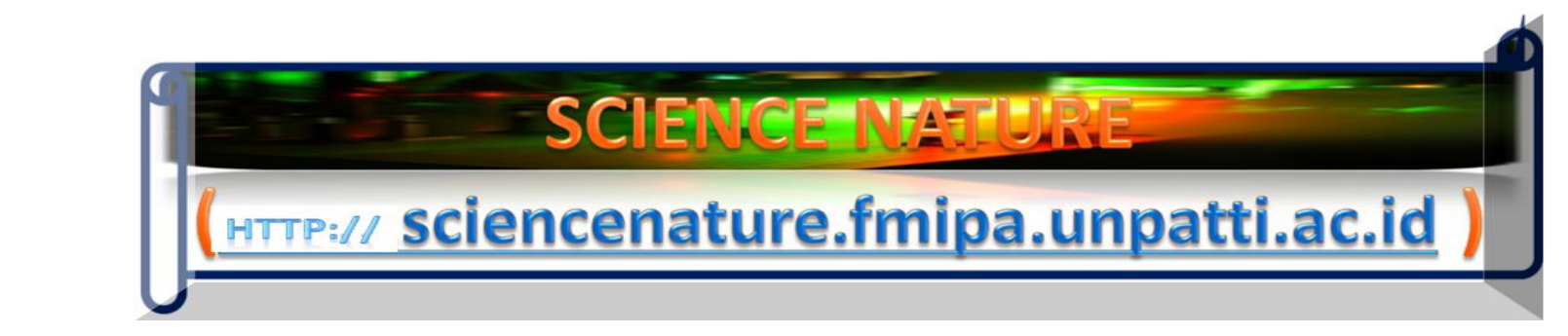

Science Nature 3(1), pp.244-256 (2020)

e-ISSN: 2654-6264

DOI: $\underline{\text { https://doi.org/10.30598/SNVol3Iss1pp244-256year2020 }}$

\title{
Is Your Brain Strong Enough to Solve Hard Problems? : Brain Vitamins as a Simple Example for Multitasking Nanotechnology Scientist
}

\author{
Hendry Izaac Elim ${ }^{0,1-6 \%}$ \\ ${ }^{0}$ Ambon Academy of Science and Arts (A-ASA), Jl. Kapitan Permata, Ambon island, Maluku province, Indonesia \\ ${ }^{1}$ Nanomaterials for Photonics Nanotechnology Laboratory (N4PN Lab.), Department of \\ Physics, Faculty of Mathematics and Natural Sciences (FMIPA), Pattimura University (UNPATTI), \\ Jl. Ir. M. Putuhena, Poka, Ambon, Indonesia 97233 \\ ${ }^{2}$ Nanotechnology Research Center and Innovative Creation (PPNRI-LPPM), \\ Research and Society Center of Pattimura University, UNPATTI, \\ Jl. Mr. CHR. Soplanit, Rumah Tiga, Ambon, Indonesia 97234 \\ ${ }^{3}$ Multidisciplinary Research Center of Excellence (MrCE), UNPATTI, J1. Dr. Leimena, Ambon, Indonesia 97234 \\ ${ }^{4}$ Multidisciplinary Bioinformatics Laboratory (MB Lab.), Biology Department, UNPATTI, Indonesia 97233 \\ ${ }^{5}$ Theoretical Physics Laboratory (TP Lab.), Department of Physics, FMIPA, UNPATTI, \\ J1. Ir. M. Putuhena, Poka, Ambon, Indonesia 97233 \\ ${ }^{6}$ Specific Laboratory of Electronics and Instrumentation, Physics Department, Pattimura University,
} Indonesia 97233

Received : March 1, 2020

Revised : March 11, 2020

Published : March 28, 2020

Copyright @ All rights are reserved by Hendry Izaac Elim

Corresponding author: ${ }^{\text {2}}$ E-mail: hendryelim@gmail.com ; Phone: +62-812 47598437 
As the number of world population reaches up to seven billion people, more complex problems will happen including broken living environmental system that is directly influenced the stress life of men. This systematic output is like the problem of aggregations and defects in material sciences identified well by physicists and nanotechnologist. As more and more smart questions are being ascended to fight against such negative impacts as well as unsolved problems in ongoing research works and its development, this paper presents a simple solution by showing a manner in such a way so that all the points of main problems and related obstacles can be guided in the truth way following by the salvation of many earthly people among the world complicated current problems and challenges. To simplify the answer and guidance for easy clarification, one took molecular electronics system (MES) of brain vitamins as the explanation for multitasking nanotechnology scientists who are in charge to carry out advanced research and its implementations in nanoscience and nanotechnology especially in exotics nanomaterials for smart nanochip fabrication. An integrated links among at least 3 different types and personalities of brain vitamins show a beautiful mind of their creator in nature of universe. The use of basic concept and principles of proposed electronic molecular system instead of mechanical or vibration system of molecules suggests that this technique is applicable for all various kind molecule structures. This idea of discovery of MES is very excellent to be applied to study many other healing system using different types of drugs.

Keywords: Strong brain, Brain vitamin, Nanoscientist, Beautiful mind.

\section{FIRST REACTIONS}

\author{
The most high quality need of human
} being is their understanding of the truth in their daily life. Holy Bible [0] as a religious book of Christian people was a collection of 66 books with 1189 chapters written from about 40 authors consisted of prophets, kings and apostles living in the interval time of prophet
The invented contribution: Significant discovery of a simple key in improving the knowledge and understanding of nano-technologist for smart multitasking technology

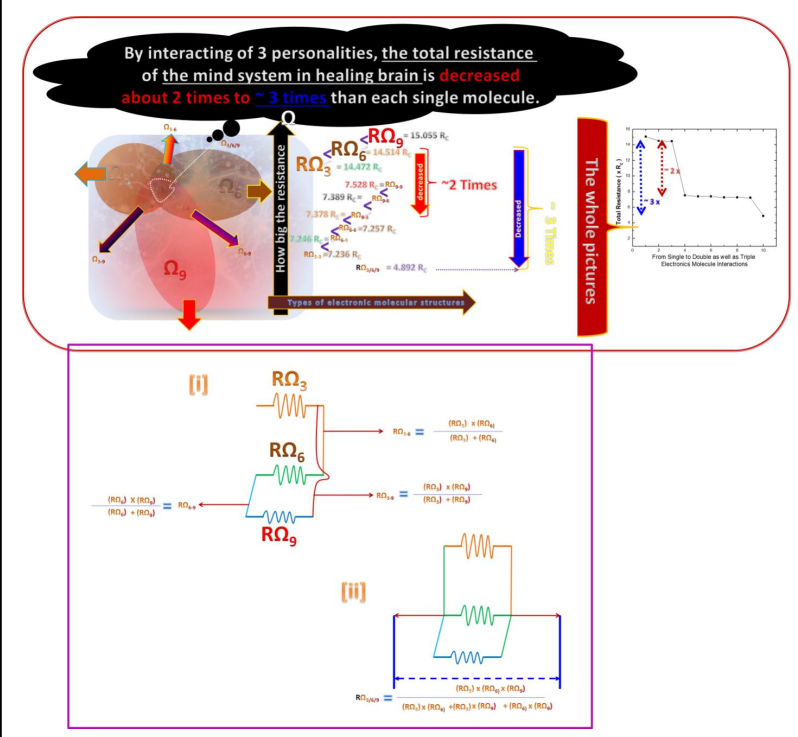

Moses to apostle John or about $\sim 1598$ years. Presently, Holy Bible has been about 3600 years old or one of the oldest books written based on facts and supraratio thinking as well as supranatural facts that involved spirits being and human flesh. The hardest question in our universe is about the essence and origin of its creation. Furthermore, such key question is normally followed by skepticism from hypocrites, and unbelievers [0]. In order to distinguish this puzzle question, one illustrates 
it into three important parts of questions as depicted in Fig. 1. In the general picture, there is a simple hard question in our daily life of people on earth: what kind of question is this?, is the question from God, Angels or Men?. Figure 1 was made based on our understanding and advanced knowledge using some captures that were actually courtesy of Holy Bible [0], and extracted from the significant contribution of Science AAAS, USA as the oldest science magazine on earth since 1849 [1], respectively. The point was that who can solve such hard questions which had not been completely solved since the presence of human being on earth, for example the smartest man on earth like Job [0] with four significant behaviors of (i) honesty, (ii) diligent in fellowship with God, (iii) character of fearing God and (iv) eschewed error/ evil. Another view of point is associated with the purpose of the most valuable hard working on earth. Such impressive thinking and its actions will show a beautiful mind of the scholar. This first reaction paper presents a part of main understanding of healing systems in human brain by the introduction of the beautiful nature of brain vitamins such as omega 9, omega 6 and omega 3 as well as their collaborative reactions. Electronics molecular system was for the first time introduced to solve the mystery knowledge behind it.

Figure 2 shows a cartoon of mystery of living memory controller which may crack the meaning of something in either your happiness of daily life or attached stress burdens to face the world. The figure was created by incorporating parts of the captures from Science AAAS [1], IOP Journal of Physics [2], and Holy Bible [0], respectively. At the end of the day of your successful life on earth will be your eternal life or life without limit [0]. This statement will make your mind a bit dizzy due to different faith extracted from a deep knowledge and understanding of something in your normal daily activities (normal life). Scientifically, it was hard to be accepted by scholars even form prominent and remarkable scientists [3-26], distinguished philosophers [27] or influenced religious leaders. For instance, this question: How come a simple man can be living forever with many genetically and biologically limitations in flesh nature surrounding by contaminated environment of human being? It was evident that Jesus Christ (JC) did it as the fact was written in Bible [0]. Our core idea here is that if you tried something and got many different failures, then you would still have opportunity to be successful in the future by repeating the works again and again like the billiard theory in nonlinear optical and chaotic science [16]. If JC could have eternal life, then you can also obtain it like the way that $\mathbf{J C}$ did before. At least, you can follow all the way that had been theoretically said, experimented and proved in space and time by $\mathbf{J C}$ from about $5 \mathbf{B C}$ to 28 AD in Israel. This was due to no doubt that the wise word contains spirit and life [0].

In order to explain this unbelievable question, one introduced a simple molecular electronics system in universe in which each single particle had their own resistance question to collaborate with another atom as shown in Fig. 3. Based on our voyage repeatable discernment of such electronics molecular system of universe $[\mathbf{0}, 3-5]$, for example as applied before in the most common antioxidant found in almost all of plants such as neo-flavonoid [5] with the total resistance was $\sim 2.795 R_{C}$, where $R_{C}$ is the carbon atom resistance. 


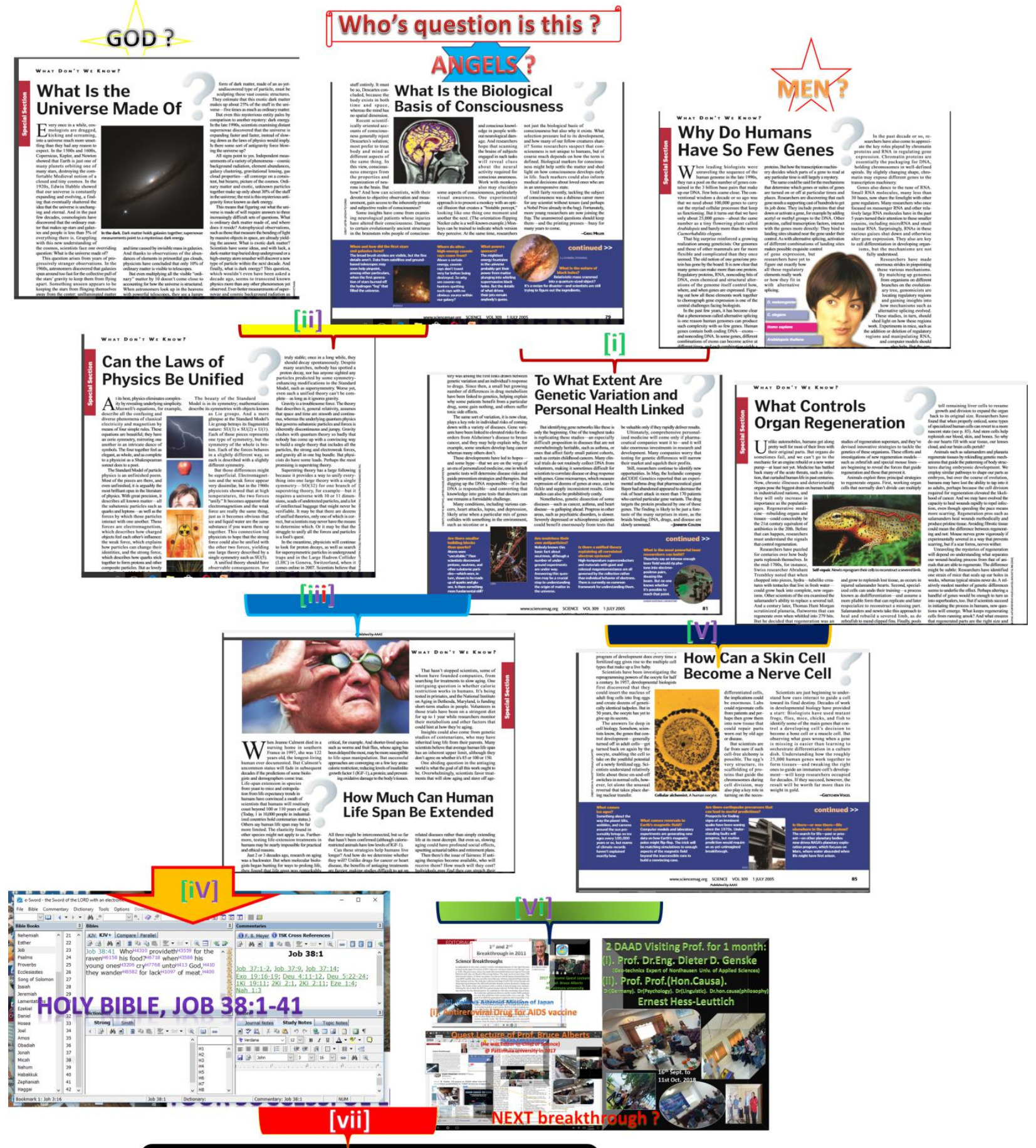

\section{$0 \ldots 1,0,0,0 . \ldots$ A GENIUS SCIENTIST ?}

Figure 1. An illustration of a simple hard question in human being daily life: The question of God, Angels or Men. Some captures were gentility of Holy Bible (e-SWORD) [0], and
Science AAAS [1], respectively. Reproduced with permission from C. Seife, et al., Special edition, Science 309, pp. 78-102 (2005). Copyright 2005 AAAS Publishing Group. 
Is Your Brain Strong Enough to Solve Hard Problems? :

Brain Vitamins as a Simple Example for Multitasking Nanotechnology Scientist

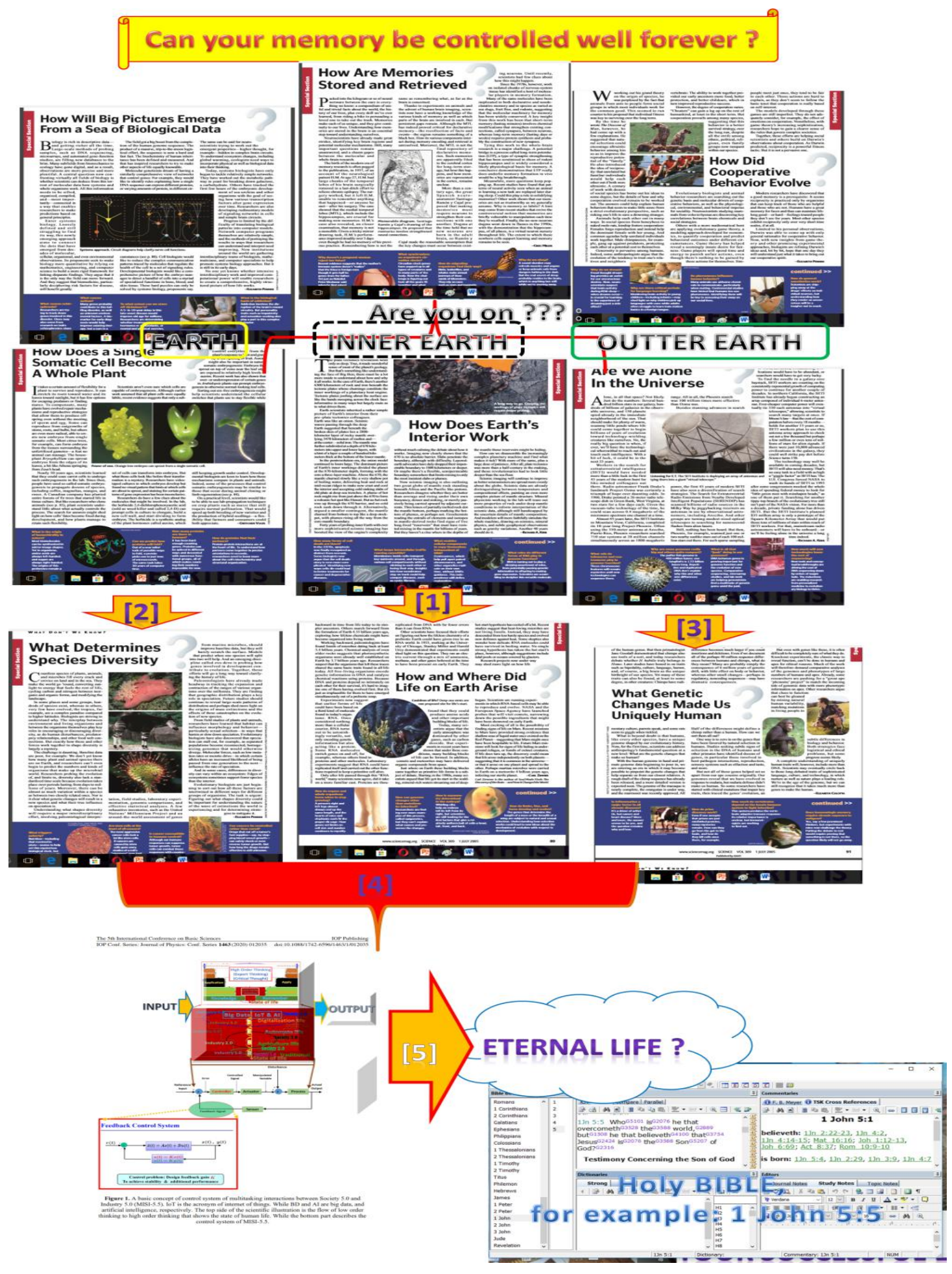

Figure 2. A cartoon of mystery of living memory controller. Parts of the captures were courtesy from Science AAAS [1], IOP Journal of Physics [2], and Holy Bible [0]. Reproduced with permission from C. Seife, et al., Special edition, Science 309, pp. 78-102 (2005) according to Copyright 2005 AAAS
Publishing Group, and H.I. Elim and G. Zhai, J. Phys.: Conf. Ser. 1463012035 (2020) based on Copyright 2020 IOP Publishing Group. 
The reason, ones converted the connection in $R_{C}$ was because carbon atom size is the largest among the other main atoms of $\mathrm{N}$, $\mathrm{O}$ and $\mathrm{H}$ as the DNA core materials [13-26] including a further electronics molecular study of the longest sand worm found in Ur-pulau, South East Maluku province [24-25]. Moreover, the most sophisticated development of nanobattery [6-12] as mobile convenient energy storage for any human being devices and instrument such as computer, hand phone and flying vehicles was started using carbon atom with many different nano-structures including carbon nanoballs, carbon nanotubes and graphene [16]. Here, the links between a living thing knowledge with energy structure materials are understandable with comprehensible evident. This was actually a novel type of philosophy called as multitasking philosophy in diversity (MPD) as the extended apprehension from former various types of world philosophies [27]. Such thought seemed like a precious individual man who can do many different works in a time such as (i) hearing, (ii) thinking, (iii) seeing, (iv) smelling, (v) touching, (vi) walking, and (vii) tasting at the same time. Therefore, when your mind was good enough, you can conduct any job with your excellent creative and innovative style.

The application of this short communication understanding for a multitasking nanotechnology scientist as the current frontier worker for a good life in our coming multidimensional future in human being history of this $21^{\text {st }}$ supermodern century was chosen to solve many complex physical problems in natural sciences or weak problems of their human brain. Brain vitamins such Omega 3, 6 and 9 as shown in Fig. 3 and Fig. 4 were good candidate for the implementation according to their diverse invented unique resistance. Figure 5 shows the molecular electronic system in brain vitamins which actually can be implemented in any types of molecules in the nature of universe.

From Fig. 6, it seems significantly that the total resistance of both single brain vitamin $\left(\boldsymbol{\Omega}_{\mathbf{9}}\right.$ or $\boldsymbol{\Omega}_{\mathbf{6}}$ or $\left.\boldsymbol{\Omega}_{\mathbf{3}}\right)$ is dependable on the number of double bonding in the similar family of structure. One obtains that the resistance of $R \boldsymbol{\Omega} \mathbf{9}$ $>\mathrm{R} \Omega_{6}>\mathrm{R} \Omega_{3}$ because of the additional number of double bonding of $\mathrm{C}=\mathrm{C}$ in those poly-unsaturated fatty acids of $\Omega_{\mathbf{6}}$ and $\Omega_{\mathbf{3}}$, respectively. On the other hand, the interactions among the same brain vitamin $\left(\boldsymbol{\Omega}_{\mathbf{9}-9}\right.$ / $\left.\boldsymbol{\Omega}_{6-6} / \boldsymbol{\Omega}_{3-3} /\right)$ as well as the interactions with different types of brain vitamins ( $\boldsymbol{\Omega}_{\mathbf{9 - 6}} / \boldsymbol{\Omega}_{\mathbf{9 - 3}} /$ $\left.\boldsymbol{\Omega}_{6-3}\right)$ and its integrated brain vitamins system of

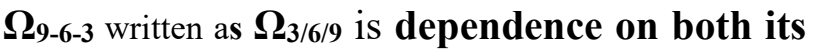
structure and the length of chain connections among atoms in such molecules. It was invented that the total resistance of interactions between two same ( $\left.\mathbf{\Omega}_{9-9} / \mathbf{\Omega}_{\mathbf{6 - 6}} / \mathbf{\Omega}_{\mathbf{3 - 3}} /\right)$ or different brain vitamins molecules $\left(\boldsymbol{\Omega}_{\mathbf{9 - 6}} / \mathbf{\Omega}_{\mathbf{9 - 3}} /\right.$ $\boldsymbol{\Omega}_{6-3}$ ) make the resistance drop as large as $\sim 2$ times from their single vitamin structure. Furthermore, as the existence of total double bonding of $\mathrm{C}=\mathrm{C}$ in the integrated brain vitamin molecule is the sum of the total $\mathrm{C}=\mathrm{C}$ in the system, the total resistance is dropped about 3 times from the single brain vitamin. It means that by incorporating an integrated type of those three brain vitamins molecules, $\Omega_{3 / 6 / 9}$ then the healing system of brain problem is more effective with 3 times resistance lower. This idea of discovery of MES is very excellent to be applied to study many other healing system using different types of drugs. 


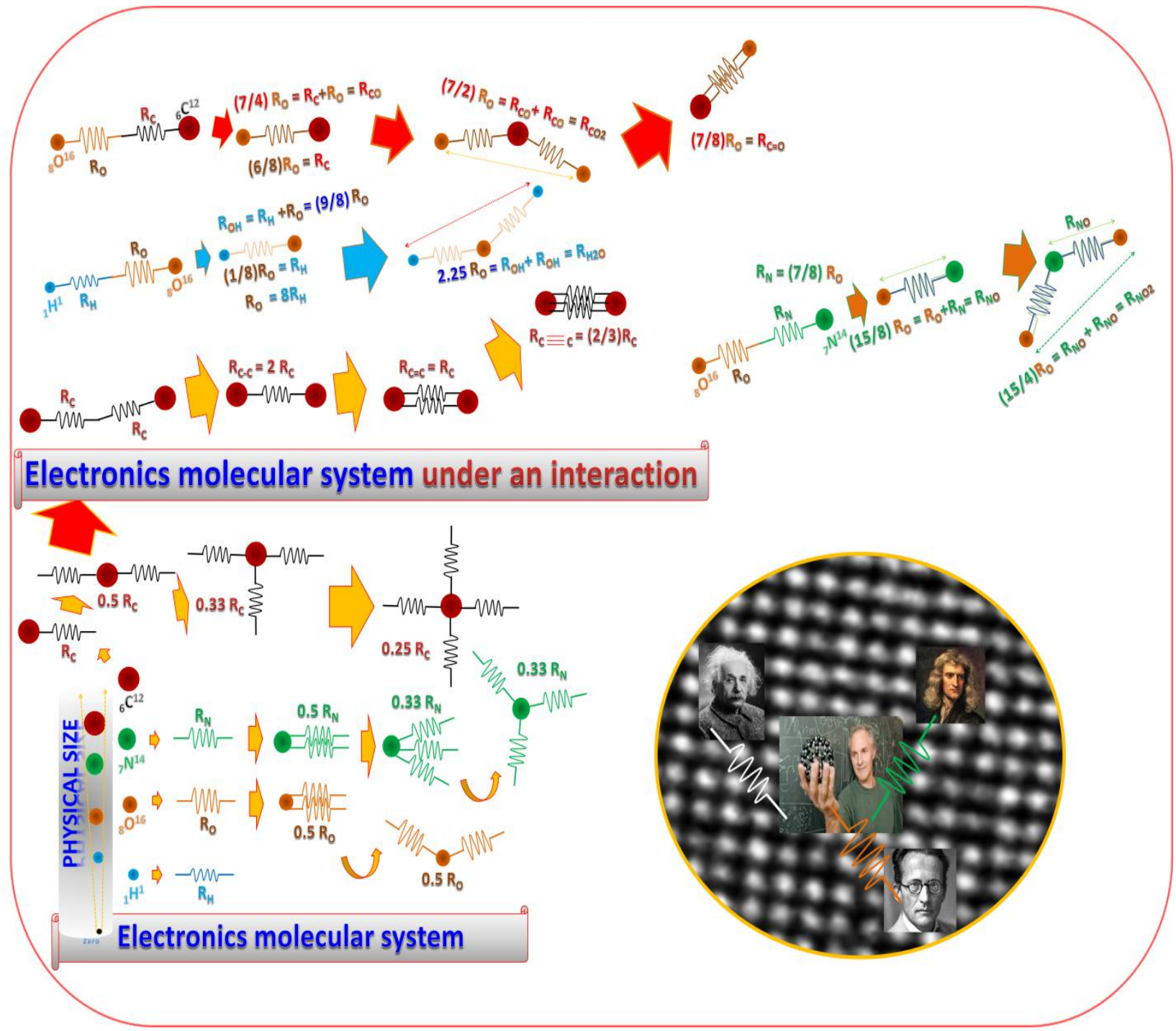

Figure 3. Basic concept and the interaction principle of electronics molecular system (MES) in its universe nature are presented. $\mathrm{R}_{\mathrm{C}}, \mathrm{R}_{\mathrm{H}}, \mathrm{R}_{\mathrm{O}}$, and $\mathrm{R}_{\mathrm{N}}$ are resistance of carbon, hydrogen, oxygen, and nitrogen atoms, respectively. 


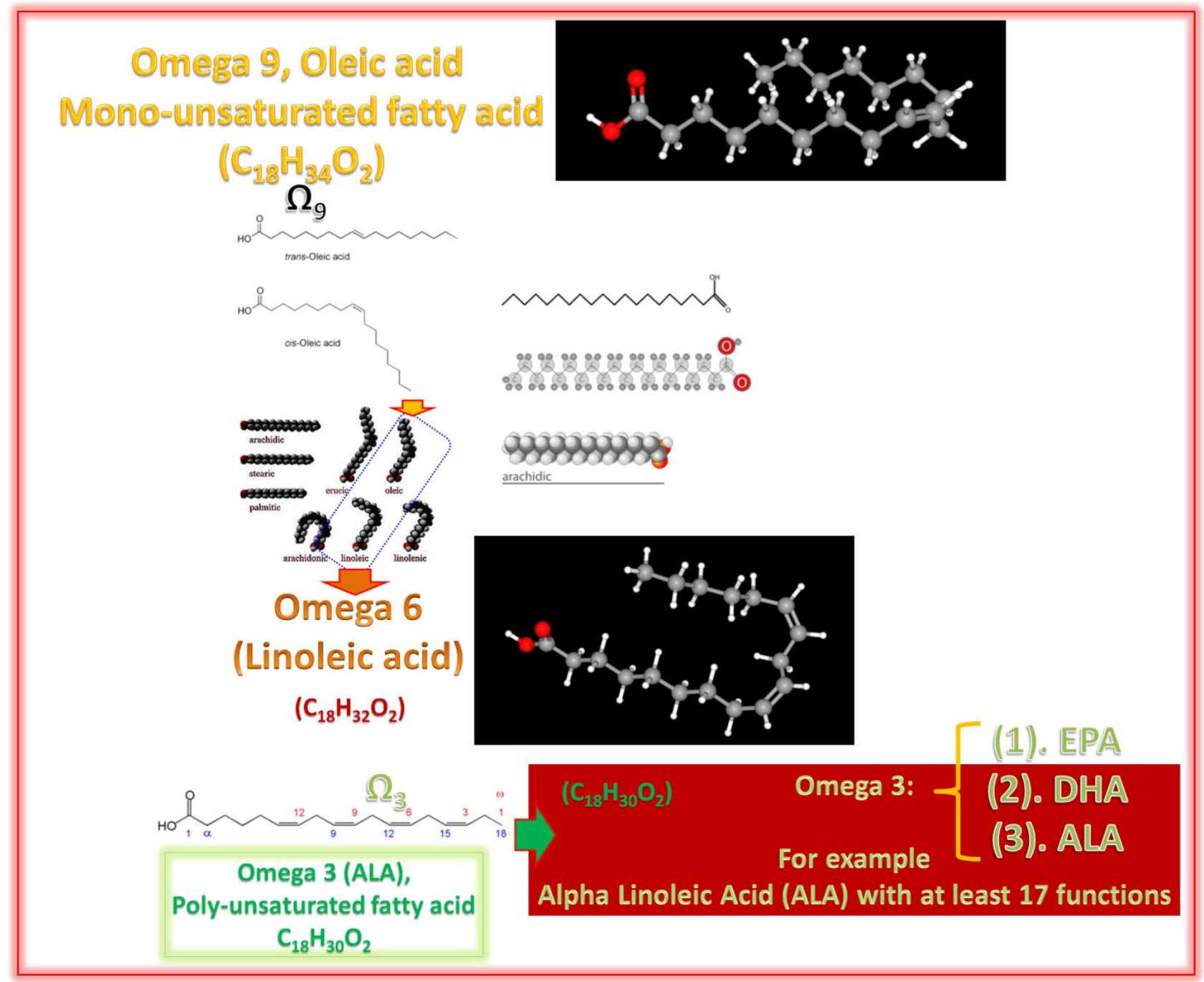

Figure 4. Basic chemical structures of fatty acids consisted of mono-unsaturated fatty acid of oleic acid called as omega $9\left(\Omega_{9}\right)$, and poly-unsaturated fatty acids consisted of omega $6\left(\Omega_{6}\right)$, and omega $3\left(\Omega_{3}\right)$. 


\section{Electronics structure behavior of brain vitamin resistance}
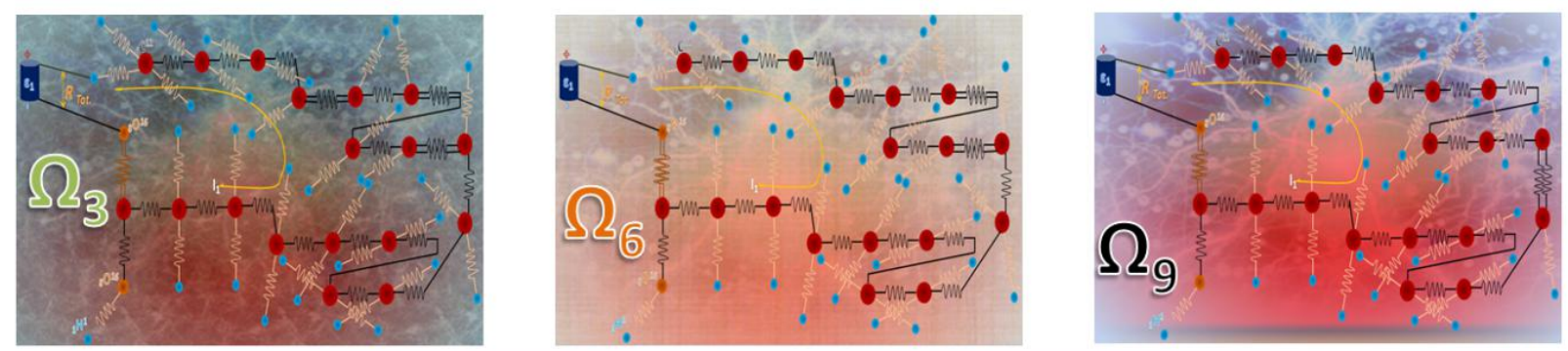

$$
\begin{aligned}
& R^{O H}\left(\Omega_{9}\right)_{T o t .}=[(7 / 18)+(49 / 6)+(7 / 6)+(16 / 3)] R_{\mathrm{C}} \\
&= {[271 / 18] R_{\mathrm{C}} } \\
& \sim 15.055 \mathrm{R}_{\mathrm{C}} \\
&\left.R^{\mathrm{OH}}\left(\Omega_{G}\right)_{\text {Tot. }}=[(7 / 18)+(84 / 12)+(21 / 24))+(7 / 6)+(16 / 3)\right] R_{\mathrm{C}} \\
&=[(7 / 18)+(339 / 24)] R_{\mathrm{C}} \\
& \sim 14.514 \mathrm{R}_{\mathrm{C}} \\
& R^{O H}\left(\Omega_{3}\right)_{\text {Tot. }}=[(7 / 18)+(91 / 12)+(7 / 6)+(16 / 3)] \mathrm{R}_{\mathrm{C}} \\
&=[(7 / 18)+(169 / 12)] \mathrm{R}_{\mathrm{C}} \\
& \sim 14.472 \mathrm{R}_{\mathrm{C}}
\end{aligned}
$$

Figure 5. The implementation of basic concept and the interaction principle of MES in its universe nature as depicted in Fig. 3 to extract the total resistance for each brain vitamins components is shown. While the $\boldsymbol{R}^{\boldsymbol{O H}}$ means the resistance was measured at the points of atom $\mathrm{O}$ and $\mathrm{H}$. 


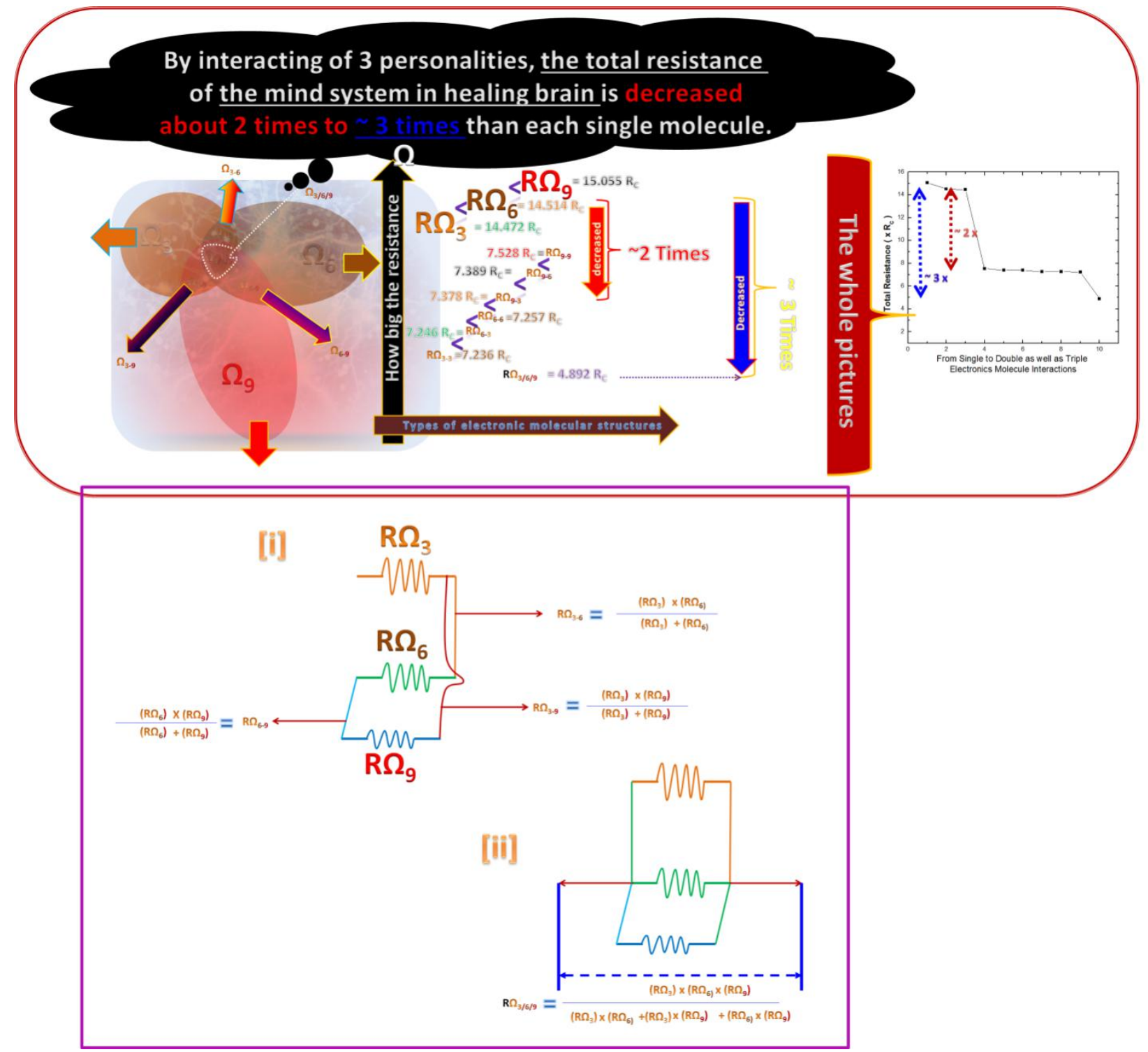

Figure 6. An example of the application of such idea from Fig. 3 to Fig. 5 for investigating the general personalities of the electronic molecular system of the interactions among $\boldsymbol{\Omega}_{\mathbf{9}}$, $\mathbf{\Omega}_{\mathbf{6}}$, and $\boldsymbol{\Omega}_{\mathbf{3}}$ which actually can be implemented in any types of molecules and nanoparticles, respectively. 
It was marvelously, such integrated brain vitamin was existed in nature for example in Laor (Polychaeta) [28], a kind of worm living in the coral reef of Maluku archipelago of the eastern part of Indonesia. Moreover, they will only appear on the surface of beach water once a year in the beginning of May about in full moon time [29]. This kind of unique coral worms (Laor) have important benefits particularly to feed shrimp and fish for human being livestock daily foods as well as human health supplements. The mystery may open a novel way for strengthening human being complex neurons system so that people will not easily get many different types of brain degradation like Alzheimer mostly suffered by American people, brain injured due to hard sports like boxing or Thai boxing, or even brain cancers arise from many muddied triggers for neuron defects in brain.

In conclusion, to solve the way of thinking problems due to many complicated heavy burden of neurons working in brain because of various pressure in our daily life, the understanding and excellent knowledge of MES is needed to anticipate the coming problems. In this significant finding of current work, we obtain that the integration of brain vitamins of $\Omega_{9}, \Omega_{6}$, and $\Omega_{3}$ are necessary especially in the structure of 3 personality molecules in 1 system, $\Omega_{3 / 6 / 9}$ in order to reduce its resistance as low as three times ( $\sim 5 R_{C}$ ) from the single brain vitamin so that the healing process is more effective and faster than the conventional one. It is interesting to point out that this discovery is exactly like the Christian belief of $1 \mathrm{God}$ in 3 different persons.

\section{Acknowledgement}

H.I.E is grateful to Pattimura university top leaders for their supports in developing research laboratory based on creativity of her each scientist. Such simple breakthrough work was funded by self-employed grant with the support of a non-profit independent organization of Ambon Academy of Science and Arts (A-ASA).

\section{Conflict of interest}

The author declares that there was no any conflicts both idea and financial with another scientists.

Bibliography

[0]. Electronics Holy BIBLE, Sword, for instance: the book of JOB, chapter 38 verses 1 to 41, Job 1:1,8, 2 Peter 3:5, Matthew 23:23, Acts 1:11, John 6:63, 1 John 5:5-9 and Psalms 53:2-3.

[1]. C. Seife, et al., Special edition, Science 309, pp. 78-102 (2005).

[2]. H.I. Elim and G. Zhai, Control System of Multitasking Interactions between Society 5.0 and Industry 5.0: A Conceptual Introduction \& Its Applications, J. Phys.: Conf. Ser. 1463012035 (2020).

[3]. H.I. Elim, Physics of Multitasking Nanomedicine, International Journal of Health Medicine and Current Research (IJHMCR) 2(03), 509-519 (2017).

[4]. H.I. Elim, Nanomedicine with Its Multitasking Applications: A View for Better Health, IJHMCR 2(02), 353-357 (2017).

[5]. H.I. Elim, and A.L. Mapanawang, Electronics Physical System of Large Antioxidant Structure in Herbal Medicine based Zingiberaceae Fruit: Understanding and Application, Nanotechnology \& Applications 1(1), (2018). DOI: 10.33425/2639-9466.1004 (ISSN: 2639-9466)

[6]. H.I. Elim, Y.W. Zhu, and C.H. Sow, Length Dependence of Ultrafast Optical Nonlinear in Vertically Aligned Multiwalled Carbon Nanotube Films, J. Phys. Chem. C 120(31), 17733-17738 (2016). 
[7]. D. Darbara, M.R. Anilkumard, V. Rajagopalanb, I. Bhattacharyac, H.I. Elim, T. Ramakrishnappaf, F.I. Ezema, R. Jose, M.V. Reddy, Studies on spinel cobaltites, $\mathrm{MCo}_{2} \mathrm{O}_{4}(\mathrm{M}=\mathrm{Mn}, \mathrm{Zn}, \mathrm{Fe}, \mathrm{Ni}$ and $\mathrm{Co})$ and their functional properties, Ceramics International 44, 4630-4639 (2018).

[8]. H.I. Elim (Elim Heaven), A.L. Mapanawang, and M.V. Reddy, A Creative Proposal to Improve Woman and Child Health: from the Knowledge of Physical Nanoscience to Nanotechnology Implementation and Products, CPQ Women and Child Health, 1(6), 01-11 (2019).

[9]. K.P. Abhilash, P. Christopher Selvin, B. Nalini, Rajan Jose, Xia Hui, H. I. Elim, M.V. Reddy, Correlation study on temperature dependent conductivity and line profile along the LLTO/LFP-C cross section for all solid-state Lithium-ion batteries, Solid State Ionics $\quad 341$, $115032 \quad$ (2019). https://doi.org/10.1016/j.ssi.2019.115032

[10].Ria Kunwar, Fabian I. Ezema, Midhun Harilal, Syam G. Krishnan, Bhupender Pal, Izan Izwan Misnon, C. R. Mariappan, H. I. Elim, Chun-Chen Yang, Rajan Jose, Pseudocapacitive Charge Storage in Thin Nanobelts, Advanced Fiber Materials 1, (2019). https://doi.org/10.1007/s42765-019-00015-w

[11]. H.I. Elim, M.V. Reddy, and R. Jose, A Frontier 2D Nanobattery: "Improving Challenges (Hotumese) and Development", Science $\begin{array}{lllll}\text { Nature 2(2), } & \text { pp. } & 114-121 & \text { (2019). } & \text { DOI: }\end{array}$ https://doi.org/10.30598/SNVol2Iss2pp114-121y2019

[12]. H.I. Elim, M. Rahman, W.S. Latupoho, R.R. Latukonsina, A.A. Pattipeilohy, M.V. Reddy, and R. Jose, Flexible Thin Battery with Fast and Sensitive Voltage Control by a Simple Mechanical Bending: No Energy without Working, Science Nature 2(3), 157-166 (2019).

[13]. H.I. Elim, and A.L. Mapanawang, The attractive differences of two types of herbal medicine from zingiberaceae fruit (golobe halmahera), International Journal of Health Medicine and Current Research 3(01), 799-806 (2018).

[14]. A.L. Mapanawang, and H.I. Elim, Unique Chemical Bonding Behavior of Love Herbal Medicine and Its Conjunction with Chemotherapy Drug, J. Nanomedicine and Nanotechnology 9(3), 1000503 (2018)
[15]. H.I. Elim, Scientific Breakthrough Based on Natural Creation: "1 Diamond with 7 Eyes", COJ Reviews and Research 1(1), pp. 1-4 (2018).

[16]. H.I. Elim, Nonlinear Optics and The Frontier of Nanoscience and Nanotechnology, Pattimura University Press, $1^{\text {st }}$ Edition, pp. 1-179 (2019). ISBN: 978-602-61906-9-7.

[17]. H. I. Elim, Theory, Implementation and the Nature of Truth (TIN) in Nanoscience, Nanotechnology, and Nanomedicine $(N N N)$ : From the Beginning of Universe to $\mathrm{nm}$ Scale Behavior, Kenkyu Journal of Nanotechnology \& Nanoscience 5, 33-36 (2019).

[18]. H. I. Elim, Multitasking Herbal Nanomedicine: A Frontier Report, Nanoscale Reports 2(1), 22-30 (2019)

[19]. Hendry Izaac Elim (Elim Heaven), The Discovery of NEW Golobe and Its Amazing Healing System, Science Nature 2(1), $\begin{array}{lll}\text { pp. } & 66-70 \quad \text { (2019). }\end{array}$ https://doi.org/10.30598/SNVol2Iss1pp066-070y2019

[20]. H.I. Elim, The First 1000 Atoms in Healing Process: From Nanotechnology to Nanomedicine, International Journal of Health Medicine and Current Research 3(04), 1044-1046 (2018). Doi: 10.22301/ijhmcr.2528-3189.1044

[21]. H.I. Elim, Metode Fisika Eksperimen: Pelengkap Teori Fisika: "To be Perfect like The 1 Who Created Our Incredible Universe", Pattimura university press, Indonesia, $1^{\text {st }}$ Edition, pp. 1-155 (2019). ISBN: 978-602-5943-05-8.

[22]. A.L. Mapanawang, and H.I. Elim, Chemical Bonding Character of Love Herbal Medicine: A Prominent Medicine Candidate for Preventing HIV virus, Nanotechnology \& Applications 1(1), 1-4 (2018). DOI: 10.33425/2639-9466.1003 (ISSN: 2639-9466).

[23]. I.F. Seay and H.I. Elim, The Observation of Fast, Long Term, and Stable Performance of Toxic Absorption in Herbal Blessing Product Based on Galoba Maluku (Zingiberaceae Fruits), $\begin{array}{lllll}\text { Science Nature 2(2), pp. } & \text { 122-127 } & \text { (2019). }\end{array}$ DOI: https://doi.org/10.30598/SNVol2Iss2pp114-127y2019

[24]. A. Masrikat and H.I. Elim, Unique Physical and Chemical Properties of Kian Sand Worm (Siphonosoma ur-pulau) Traditional Medicine: Electrical, Optical and Chemical Response of Edible Powder with Different Sizes, Biochemistry and Modern Applications 2(1), 51-54 (2019). https://doi.org/10.33805/2638-7735.123

[25]. A. Masrikat, Y. Noya, and H.I. Elim, Image Processing and Optical-Electricity Property of Traditional Medicine Products 
from Kian Sand Worm (Siphonosoma ur-pulau), Science Nature 2(3), pp.148-156 (2019).

[26]. H.I. Elim, Panduan Skripsi Sarjana Sains (S.Si), Pattimura University Press, $1^{\text {st }}$ Edition, pp. 1-44 (2019). ISBN: 978-602-61906-8-0.

[27]. H.I. Elim, Esther Kembauw, Reico H. Siahainenia, Jacobus S.A. Lamerkabel, Aphrodite M. Sahusilawane, Sri Wahyuni Djoko, and Beni Setha, Heavenly Small Islands Simple Technology \& Its Cultural Economy Impacts in Maluku, Indonesia: a New Proposed Multitasking Philosophy in Diversity (MPD), Science Nature 2(4), pp.192-207 (2019). e-ISSN: 2654-6264 . DOI: https://doi.org/10.30598/SNVol2Iss4pp192-207year2019

[28]. S. Kudo, F. Antara, and H.C. Petrus, The effect of consumption of worm laor (polychaeta) on reducing high blood pressure in patients with hypertension in the work area of kusuri the health center in the west tobelo district, North Halmahera regency, International Journal of Health Medicine and Current $\begin{array}{llll}\text { Research } & 5(01), & 1610-1621 & \text { (2020). }\end{array}$ 10.22301/IJHMCR.2528-3189.1610

[29]. S. Liline, M. Amin, U. Lestari, and A.D. Corebima, The Identification of Laor Worms (Polychaeta) in Marine Areas of Ambon Island, Mollucas Province,Indonesia Based on 16s rRNA Gene Sequence, International Journal of ChemTech Research 9(06), pp 307-315, (2016). ISSN: 0974-4290, ISSN(Online):2455-9555.

\section{Corresponding Author Short CV}

Assoc.Prof. H.I. Elim, Ph.D is a simple physicist at Pattimura university from Indonesia small island of Ambon in Maluku (Melaka in Hebrew meaning King) province, the province with about 1344 small islands or the province of kings. I am the leading scientist on physics of nanoscience and nanotechnology from the east part of Indonesia with the national rank about 31st among 250,000 whole Indonesia current scientists. My best achievement in physical sciences output is with $\mathrm{h}$ index according to WoS or Scopus of 24 and total citations 2480 from up to 85 papers. Currently, I am the Editor-in-Chief of an inventor journal called as SCIENCE NATURE.

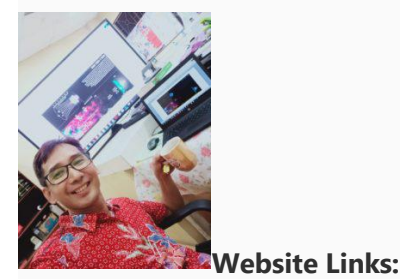

http://sciencenature. fmipa. unpatti. ac. id/index. php/editor $\underline{\text {-in-chief-of-science-nature/ }}$

ORCID ID: 0000-0002-4272-7115 